\author{
Ewa Świstak, Wacław Laskowski \\ Katedra Organizacji i Ekonomiki Konsumpcji \\ Szkoła Główna Gospodarstwa Wiejskiego w Warszawie
}

\title{
Zmiany wzorca konsumpcji żywności na wsi i ich uwarunkowania
}

\section{Wstęp}

$\mathrm{Na}$ określenie sposobu odżywiania się różnych grup ludności używa się wymiennie pojęć ,wzorzec” lub „model” spożycia żywności, przy czym drugie z nich częściej stosowane jest w odniesieniu do przyszłości, stanowiąc teoretyczną koncepcję przyszłej konsumpcji ${ }^{1}$. Z kolei przez wzorzec spożycia żywności należy rozumieć empirycznie stwierdzoną, rzeczywistą konstrukcję, uznaną i respektowaną społecznie, odzwierciedlającą istniejące preferencje i przyzwyczajenia. Wzorzec zatem ukazuje poziom i strukturę spożycia wraz z ich uwarunkowaniami ${ }^{2}$, pełniąc funkcję diagnostyczną. Identyfikacja wzorców spożycia żywności może być dokonywana zarówno na poziomie przeciętnym, ogólnokrajowym, jak i charakterystycznym dla określonych grup ludności, wyodrębnionych według takich kryteriów jak na przykład miejsce zamieszkania czy przynależność do grupy społeczno-ekonomicznej. Celem pracy była analiza spożycia żywności w wiejskich gospodarstwach latach: 2000, 2005 i 2012 oraz zweryfikowanie tezy o zmianie tradycyjnego wiejskiego wzorca konsumpcji żywności w kierunku modelu miejskiego w efekcie zmian gospodarczo-ekonomicznych i społeczno-demograficznych obserwowanych po akcesji Polski do UE.

\footnotetext{
${ }^{1}$ Wiszniewski E., Ekonomika konsumpcji, PWN, Warszawa 1983.

${ }^{2}$ Kamiński W,. 1980: Polityka i organizacja żywienia ludności, PWE, Warszawa, s.114.
} 


\section{Wybrane czynniki kształtujące wiejski wzorzec konsumpcji żywności}

Włączenie Polski w struktury Unii Europejskiej zapoczątkowało szereg procesów o charakterze gospodarczym i politycznym, które miały reperkusje demograficzne i ekonomiczne w gospodarstwach domowych. Sytuację rolnictwa kształtowały głównie takie czynniki, jak: poziom cen surowców rolnych i środków produkcji, wsparcie finansowe, w tym pochodzące $\mathrm{z}$ budżetu UE oraz ustalenia wspólnej unijnej polityki rolnej. W ich efekcie w latach 2005-2006 poprawiła się ogólna koniunktura w rolnictwie ${ }^{3}$, co jednak nie znalazło odzwierciedlenia w strukturze wytworzonego PKB, w którym znacząco zmalał udział rolnictwa (spadek z 4,4\% w 2000 roku do 2,9\% w 2005 roku) przede wszystkim na rzecz szeroko pojętego sektora usług. W dłuższej perspektywie, między rokiem 2002 a 2011 (lata spisu powszechnego) o ponad 300 tysięcy zmalała liczba zatrudnionych $\mathrm{w}$ rolnictwie, a także zmniejszył się odsetek mieszkańców wsi, dla których rolnictwo stanowiło źródło utrzymania z ponad 10 do $7 \%{ }^{4,5}$.

Inny kierunek zmian dotyczył struktury demograficznej ze względu na miejsce zamieszkania. Liczba mieszkańców wsi w 2011 roku, w porównaniu z 2002 rokiem, była o ponad 3\% wyższa, natomiast miast - prawie o $1 \%$ niższa. W efekcie w 2002 roku ludność wiejska stanowiła 38,2\% mieszkańców Polski, w 2011 roku jej udział wzrósł o 1 punkt procentowy (rysunek 1). Tradycyjnie wieś charakteryzuje się większą dzietnością, co potwierdzają analizowane dane ze spisów powszechnych - przeciętna liczba osób w rodzinie wiejskiej wzrosła między rokiem 2002 i 2011 z 3,33 do 3,40, natomiast w miastach spadła z 2,6 do 2,54 . Jednak liczba dzieci do 24 lat pozostających na utrzymaniu rodziny zmalała w tym okresie zarówno na wsi (o 13\%), jak i w mieście (o ponad 21\%).

Przyrost liczby ludności na wsiach w latach 2005-2013 dotyczył zarówno osób w wieku produkcyjnym (o 8\%), jak i poprodukcyjnym (o 9\%), natomiast w miastach ubyło mieszkańców w wieku produkcyjnym (o prawie 4,5\%), przy jednoczesnym wzroście aż o $27 \%$ osób w wieku poprodukcyjnym (rysunek 2).

Do zmian w strukturze demograficznej przyczyniły się także procesy migracyjne. Od 2000 roku na terenach wiejskich obserwuje się dodatni bilans wewnętrznych migracji ludności, zwłaszcza w podmiejskich strefach dużych aglomeracji. Proces ten ma charakter dynamiczny: w 2000 roku saldo migracji we-

\footnotetext{
${ }^{3}$ Poczta W., 2008: Wpływ integracji Polski z Unią Europejską na sytuacje ekonomiczną sektora rolnego w latach 2004-2006. Wieś i Rolnictwo 1, 138, s. 19-33.

${ }^{4}$ Rocznik Statystyczny Rolnictwa 2014, Zakład Wydawnictw Statystycznych, Warszawa.

${ }^{5}$ Zegar J.S., 2015: Polskie rolnictwo w okresie dwóch przełomów - transformacji ustrojowej i integracji europejskiej. Nierówności Społeczne a Wzrost Gospodarczy nr 41, s. 156.
} 


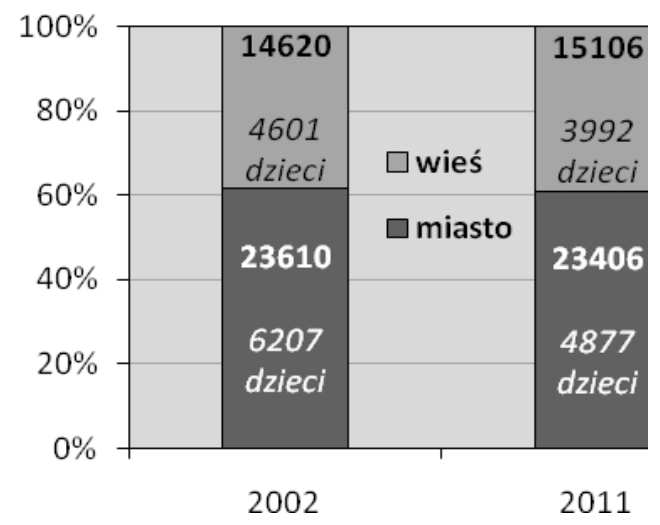

\section{Rysunek 1}

Ludność ${ }^{*}$ wiejska i miejska w latach 2002 i 2011, w tym liczba dzieci pozostających na utrzymaniu rodziny

*wg spisów powszechnych.

Źródło: Opracowanie własne na podstawie Rocznika Statystycznego Rzeczypospolitej Polskiej 2014.

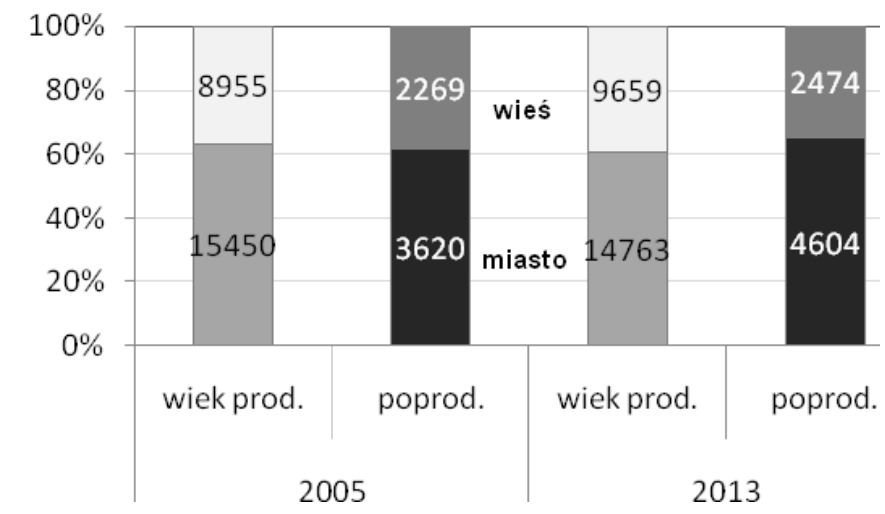

\section{Rysunek 2}

Zmiany ludności w wieku produkcyjnym i poprodukcyjnym na wsi i w mieście Źródło: Opracowanie własne na podstawie Rocznika Statystycznego Rzeczypospolitej Polskiej 2014.

wnętrznej dla wsi wyniosło 4,2 tys. osób, w 2005 roku 32,6 tys., a w 2013 roku już 37,8 tys. ${ }^{6}$.

Z badań CBOS wynika, że przybysze z miast stanowią aktualnie około $8 \%$ całej ludności wiejskiej. Na wsi szukają najczęściej spokoju i kontaktu z naturą. Wśród nich dominują osoby z co najmniej średnim wykształceniem (63\%),

\footnotetext{
${ }^{6}$ Rocznik Statystyczny Rzeczypospolitej Polskiej 2014, Zakład Wydawnictw Statystycznych, Warszawa.
} 
utrzymujące się z pracy najemnej (44\%) lub ze źródeł niezarobkowych (34\%). Osoby pracujące na ogół dojeżdżają do pracy poza miejsce zamieszkania, a tylko około $18 \%$ trudni się rolnictwem. Dla porównania spośród pracujących rdzennych mieszkańców wsi 28\% utrzymuje się z rolnictwa, a z pozostałych większość pracuje poza miejscem zamieszkania. Cechuje ich też gorsza od ludności napływowej sytuacja materialna ${ }^{7}$.

Dobra koniunktura w rolnictwie odnotowana w latach 2005-2006 zaowocowała poprawą sytuacji dochodowej gospodarstw, ale głównie tych o największej powierzchni użytków rolnych. Dominujące w Polsce gospodarstwa średnie i małe, stanowiące $90 \%$ wszystkich i skupiające 55\% polskich zasobów użytków rolnych, odczuły ją w niewielkim stopniu. Ponadto, mimo poprawy, nie nastapiło zrównanie sytuacji dochodowej rolników z innymi grupami zawodowymi ${ }^{8}$. W latach 2000 -2012 dochód osiaggany przez przeciętną osobę utrzymującą się z rolnictwa rósł bardziej dynamicznie niż średni dochód członka polskiego gospodarstwa domowego (tabela 1), ale nie osiagnął jego poziomu (w 2012 roku był o $15 \%$ niższy).

\section{Tabela 1}

Miesięczny dochód i wydatki przeciętnego członka gospodarstwa domowego w latach 2000,2005 i 2012

\begin{tabular}{|l|c|c|c|c|c|c|}
\hline \multirow{2}{*}{ Wyszczególnienie } & \multicolumn{3}{|c|}{ Gospodarstwa ogółem } & \multicolumn{3}{c|}{ Gospodarstwa rolników } \\
\cline { 2 - 7 } & 2000 & 2005 & 2012 & 2000 & 2005 & 2012 \\
\hline $\begin{array}{l}\text { Dochód rozporządzalny } \\
\text { (PLN) }\end{array}$ & 610,5 & 761,5 & 1278,4 & 456,0 & 606,2 & 1091,6 \\
\hline Wydatki ogółem (PLN) & 599,5 & 690,3 & 1050,8 & 442,0 & 533,9 & 784,6 \\
\hline $\begin{array}{l}\text { Wydatki na żywność i napoje } \\
\text { bezalkohol. (PLN) }\end{array}$ & 184,8 & 194,1 & 263,9 & 184,2 & 192,8 & 249,9 \\
\hline $\begin{array}{l}\text { Udział wydatków na żywność } \\
\text { w wydatkach ogółem (\%) }\end{array}$ & 30,8 & 28,1 & 25,1 & 41,7 & 36,1 & 31,8 \\
\hline
\end{tabular}

Źródło: Opracowanie własne na podstawie Roczników Statystycznych Rzeczypospolitej Polskiej 2007 i 2014.

Dobrym wskaźnikiem stopnia zamożności rodziny jest udział wydatków na żywność w wydatkach ogółem. Z prawa Engla wynika, że wraz ze wzrostem dochodów szybciej rosną wydatki na artykuły nieżywnościowe niż na żywność. W efekcie czego udział wydatków na żywność w wydatkach ogółem maleje. Jak wynika z tabeli 1, w każdym z analizowanych lat porównywane wskaźniki były niekorzystne dla gospodarstw wiejskich i świadczyły o gorszej od przeciętnej sytuacji finansowej rodzin rolników.

\footnotetext{
${ }^{7}$ Wieś polska - rdzenni i nowi mieszkańcy. Komunikat z badań CBOS, BS/120/2013 Warszawa, sierpień 2013. www.cbos.pl

${ }^{8}$ Poczta W., 2008: Wpływ integracji Polski z Unią Europejską na sytuacje ekonomiczną sektora rolnego w latach 2004-2006. Wieś i Rolnictwo 1, 138, s. 19-33.
} 


\section{Materiał i metodyka}

Materiał badawczy stanowiły niepublikowane indywidualne wyniki badań budżetów gospodarstw domowych prowadzonych przez GUS, dotyczace wielkości spożycia 64 grup produktów żywnościowych w gospodarstwach domowych w Polsce. Okres badawczy obejmował lata: 2000, 2005 i 2012 (przed akcesja do UE, rok po akcesji i 8 lat po akcesji). Na potrzeby niniejszego opracowania wyodrębniono i zagregowano dane według kryterium przynależności do grupy społeczno-zawodowej oraz miejsca zamieszkania, wykorzystując w tym celu programy komputerowe: MS Access 2010 oraz Statistica 12.5

Analizą objęto:

- $\quad$ wzorzec konsumpcji żywności realizowany w gospodarstwach domowych rolników (czyli utrzymujących się głównie z pracy we własnym gospodarstwie), przyjmując za punkt odniesienia spożycie żywności w przeciętnym polskim gospodarstwie domowym;

- $\quad$ wiejski wzorzec konsumpcji realizowany przez gospodarstwa domowe osób mieszkających na wsi (zarówno rolników, jak i osób utrzymujących się ze źródeł innych niż praca we własnym gospodarstwie rolnym) porównany do przeciętnego spożycia żywności przez członków rodzin zamieszkujących małe miasta (poniżej 20 tysięcy mieszkańców).

W obu przypadkach dane o spożyciu zagregowano do 13 podstawowych grup artykułów żywnościowych, zwracając uwagę na najważniejsze różnice w ich strukturze.

Dla gospodarstw rolników dokonano ponadto żywieniowej oceny przeciętnej diety poprzez porównanie spożycia żywności wyrażonego w energii i składnikach odżywczych ze średnioważoną normą żywienia. Wartość energetyczną i odżywczą racji pokarmowej wyznaczono z zastosowaniem przeliczników, opracowanych na podstawie tabel Składu i Wartości Odżywczej Żywności ${ }^{9}$. Średnioważoną normę żywienia dla gospodarstw rolników obliczono na podstawie Norm żywienia dla populacji polskiej ${ }^{10}$, struktury demograficznej gospodarstw rolniczych oraz przyjętej aktywności fizycznej (norma ta ma charakter orientacyjny, pozwala jedynie wskazać potencjalne problemy żywieniowe w omawianej populacji i przeanalizować zmiany w czasie). Ponieważ badania budżetów nie odzwierciedlają faktycznego spożycia, a jedynie ilość żywności, która trafiła do gospodarstwa domowego, więc przed porównaniem z normą dokonano redukcji spożycia o przeciętne straty składników odżywczych, powsta-

\footnotetext{
${ }^{9}$ Kunachowicz H., Przygoda B. Nadolna I., Iwanow K. (2005): Tabele Składu i Wartości Odżywczej Żywności, Wyd. Lekarskie PZWL, Warszawa.

${ }^{10}$ Normy żywienia dla populacji polskiej - nowelizacja, red. naukowy M. Jarosz, IŻŻ, 2012, www.izz.waw.pl
} 
jące $\mathrm{w}$ trakcie przygotowywania posiłków (o $15-25 \%$ dla witamin i $10 \%$ dla pozostałych składników odżywczych) ${ }^{11}$.

\section{Wyniki badań}

Tradycyjny wzorzec spożycia żywności w gospodarstwach wiejskich różnił od innych wyższy poziom konsumpcji większości artykułów spożywczych, z wyjątkiem ryb i owoców. Taką sytuację uzasadniał charakter pracy na wsi, wymagający wysokich wydatków energetycznych i łatwy dostęp do produktów pochodzących z własnego gospodarstwa. Ponadto zjawiskiem dość powszechnym na wsi jest przeznaczanie na skarmianie zwierząt części produktów żywnościowych, które $\mathrm{w}$ badaniach budżetów gospodarstw domowych mogą być wykazywane jako konsumowane przez członków gospodarstwa. Analiza spożycia w 2000 roku (tabela 2) potwierdza wymienione wcześniej cechy wzor-

\section{Tabela 2}

Poziom spożycia żywności w gospodarstwach rolników (w kg na osobę rocznie) w porównaniu do przeciętnego polskiego gospodarstwa domowego w latach 2000, 2005 i 2012

\begin{tabular}{|l|c|c|c|c|c|c|}
\hline \multirow{2}{*}{ Grupy produktów } & \multicolumn{2}{|c|}{2000} & \multicolumn{2}{c|}{2005} & \multicolumn{2}{c|}{2012} \\
\cline { 2 - 7 } & $\begin{array}{c}\text { Gosp. } \\
\text { rolników }\end{array}$ & *R/O \% & $\begin{array}{c}\text { Gosp. } \\
\text { rolników }\end{array}$ & *R/O \% & $\begin{array}{c}\text { Gosp. } \\
\text { rolników }\end{array}$ & *R/O \% \\
\hline Produkty zbożowe & 131,9 & 114 & 125,7 & 115 & 97,2 & 111 \\
\hline Mięso i przetwory & 80,6 & 117 & 76,6 & 109 & 77,9 & 109 \\
\hline Ryby i przetwory & 4,5 & 82 & 5,7 & 104 & 4,8 & 87 \\
\hline Mleko i przetwory & 125,4 & 136 & 93,5 & 112 & 82,1 & 107 \\
\hline Jaja (w szt.) & 221 & 119 & 223 & 113 & 229 & 115 \\
\hline Masło & 3,5 & 88 & 4,2 & 104 & 2,8 & 84 \\
\hline Tłuszcze roślinne & 12,5 & 94 & 16,6 & 123 & 12,9 & 101 \\
\hline Tłuszcze zwierzęce & 5,5 & 190 & 3,5 & 130 & 2,6 & 156 \\
\hline Owoce i przetwory & 49,3 & 93 & 48,8 & 99 & 41,2 & 86 \\
\hline Warzywa i przetw. & 76,2 & 113 & 82,1 & 112 & 69,6 & 100 \\
\hline Strączkowe suche & 1,3 & 117 & 1,2 & 130 & 0,6 & 103 \\
\hline Ziemniaki & 116,2 & 118 & 111,8 & 130 & 82,1 & 140 \\
\hline Cukier i przetwory & 35,2 & 119 & 30,2 & 109 & 28,4 & 118 \\
\hline
\end{tabular}

*Relacja poziomu spożycia w gospodarstwach rolników (R) do przeciętnego spożycia w gospodarstwach domowych ogółem (O) przyjętego za 100\%.

Źródło danych do obliczeń własnych: GUS, badanie budżetów gospodarstw domowych. GUS nie ponosi odpowiedzialności za dane i wnioski zawarte w publikacji.

\footnotetext{
${ }^{11}$ Normy żywienia dla populacji polskiej - nowelizacja, red. naukowy M. Jarosz, IŻŻ, 2012, www.izz.waw.pl
} 
ca. Rolnicy konsumowali o 14-19\% więcej dziewięciu spośród analizowanych trzynastu grup produktów żywnościowych. Nieco mniej niż przeciętnie spożywano tłuszczów roślinnych i masła, ale za to prawie dwukrotnie więcej innych tłuszczów zwierzęcych (gł. słoniny i smalcu), co również jest zgodne z wzorcem tradycyjnym. Na poziomie bliskim przeciętnemu dla ogółu gospodarstw domowych spożywano owoce, co oznaczało korzystną zmianę w stosunku do lat wcześniejszych. Spożycie ryb w gospodarstwach rolników było o $18 \%$ niższe niż średnie w Polsce.

Wśród zmian, jakie zaszły we wzorcu konsumpcji realizowanym przez rolników w 2005 roku, można znaleźć zarówno aspekty pozytywne, jak i negatywne z żywieniowego punktu widzenia. Do pozytywów można zaliczyć wzrost spożycia owoców, ryb oraz zmianę struktury konsumowanych tłuszczów będącej następstwem większego spożycia tłuszczów roślinnych i masła oraz dwukrotnego spadku spożycia innych tłuszczów zwierzęcych. Korzystną zmianą był także spadek konsumpcji cukru i jego przetworów. Negatywne aspekty zmian wzorca były analogiczne dla tych, które obserwowano we wszystkich gospodarstwach domowych i wyrażały się spadkiem konsumpcji zbożowych, ziemniaków, mleka i owoców, a na wsi dodatkowo także warzyw. W efekcie zaobserwowanych zmian wiejski wzorzec konsumpcji upodobnił się do przeciętnego dla gospodarstw domowych w zakresie spożycia ryb i owoców i zachował ilościową przewagę w odniesieniu do większości pozostałych grup produktów. W 2005 roku, w relacji do średniego dla ogółu grup, wiejski wzorzec konsumpcji był najbardziej optymalny spośród trzech analizowanych lat.

Sytuacja wyraźnie zmieniła się w 2012 roku. W gospodarstwach rolników zaobserwowano spadek spożycia większości artykułów żywnościowych, z wyjątkiem mięsa i jaj. Spadek odnotowano także dla ogółu grup społeczno-zawodowych, ale był on mniej znaczący. Przykładowo spożycie mleka i przetworów w gospodarstwach ogółem obniżyło się o $7 \%$, a u rolników - o $12 \%$, owoców odpowiednio o 3 i $16 \%$, warzyw o 5,5 i 15\%. W efekcie wiejski wzorzec konsumpcji w relacji do ogólu grup gospodarstw domowych ponownie zbliżył się do „tradycyjnego" w zakresie niższego spożycia ryb i owoców, a także dominacji w spożyciu thuszczów zwierzęcych, ziemniaków, jaj, zbożowych i cukru. Dla pełniejszej oceny aktualnego wiejskiego wzorca konsumpcji żywności należy zwrócić uwagę na strukturę poszczególnych grup produktów. Do 11\% przewagi rolników w spożyciu zbożowych przyczyniła się wysoka konsumpcja pieczywa mieszanego i mąki, podczas gdy spożycie ryżu w tych gospodarstwach było najniższe. $Z$ grupy mięso i przetwory gospodarstwa rolników preferują wyraźnie mięso wieprzowe, którego konsumują zdecydowanie więcej niż inne typy rodzin. Rolnicy należą także do grup o wysokim spożyciu drobiu. Znacznie mniej natomiast konsumują mięsa wołowego i wędlin drobiowych. Niskie spożycie 
ryb na wsi ograniczone jest dodatkowo przede wszystkim do śledzi i konserw rybnych. Spośród produktów mlecznych, do tych, w konsumpcji których dominują gospodarstwa rolnicze należą: mleko, śmietana i sery twarogowe, natomiast w niewielkich ilościach spożywane są jogurty, napoje mleczne i sery dojrzewające. Do owoców konsumowanych przez rolników na poziomie zbliżonym do innych grup należą jabłka i śliwki, a zdecydowanie mniej na wsi spożywa się owoców południowych. O silnej pozycji warzyw w wiejskim wzorcu konsumpcji decyduje głównie wysokie spożycie kapusty, a także buraków, marchwi i innych korzeniowych. Z grupy cukier i przetwory gospodarstwa wiejskie w największych ilościach spożywają cukier, a mniej niż inne typy gospodarstw - przetworów cukierniczych.

Dominacja w spożyciu jaj, tłuszczów zwierzęcych i ziemniaków oraz przedstawiona struktura spożycia pozostałych grup produktów żywnościowych wskazuje na bazowanie gospodarstw rolników na artykułach pochodzących z samozaopatrzenia oraz tańszych, nieprzetworzonych nabywanych w sklepach i na bazarach. Wobec faktu, że wzrost zamożności skutkuje zwykle ograniczaniem poziomu samozaopatrzenia ${ }^{12}$, można wnioskować o nienajlepszej kondycji tych gospodarstw.

Efektem zmian obserwowanych we wzorcu konsumpcji są zmiany w wartości energetycznej i odżywczej przeciętnej racji pokarmowej. W 2012 roku, w stosunku do 2000 we wszystkich grupach społeczno-zawodowych miało miejsce obniżenie zawartości w diecie prawie wszystkich analizowanych składników pokarmowych (tabela 3). Jedyny wyjątek dotyczył witaminy E, co w przypadku ogółu gospodarstw mogło mieć związek z nieco wyższym w 2012 roku spożyciem jaj i warzyw, a w przypadku gospodarstw rolników - jaj i thuszczów roślinnych. Stwierdzone obniżenie wartości energetycznej i odżywczej racji pokarmowej w znacznie większym stopniu dotyczyło gospodarstw rolników niż ogółu grup. Wprawdzie utrzymała się przewaga rodzin wiejskich w spożyciu większości składników pokarmowych, ale zmalała ona na ogół z kilkunastu do kilku procent. Tylko poziom weglowodanów i witaminy $\mathrm{B}_{1} \mathrm{w}$ dietach rolników był w 2012 r. odpowiednio o 14 i 15\% wyższy od przeciętnego dla ogółu gospodarstw domowych.

Porównanie wartości energetycznej i odżywczej spożycia w gospodarstwach rolników ze średnioważoną normą żywienia pozwala na stwierdzenie, iż zaobserwowane zmiany były niekorzystne z żywieniowego punktu widzenia (rysunek 3). W 2012 roku niedobory odnotowano w spożyciu prawie wszystkich składników odżywczych (z wyjątkiem tłuszczu), podczas gdy w roku 2000 dotyczyły one w zasadzie tylko wapnia, żelaza i witaminy C.

\footnotetext{
${ }^{12}$ Kowrygo B., 2000: Studium wpływu gospodarki rynkowej na sferę żywności i żywienia w Polsce. Wyd. SGGW, Warszawa, s. 187.
} 
Tabela 3

Wartość energetyczna i odżywcza przeciętnej racji pokarmowej w gospodarstwach domowych w Polsce w latach 2000 i 2012 (na osobę dziennie)

\begin{tabular}{|l|c|c|c|c|c|c|}
\hline \multirow{2}{*}{ Składnik odżywczy } & \multicolumn{3}{|c|}{2000} & \multicolumn{3}{|c|}{2012} \\
\cline { 2 - 3 } & \multicolumn{2}{|c|}{ Gosp. domowe } & \multirow{2}{*}{$\begin{array}{c}\text { *R/O } \\
\text { [\%] }\end{array}$} & \multicolumn{2}{|c|}{ Gosp. domowe } & *R/O \\
\cline { 2 - 3 } & ogółem & rolników & ogółem & rolników & [\%] \\
\hline Energia [kcal] & 2511 & 2860 & 114 & 2164 & 2365 & 109 \\
\hline Białko [g] & 75 & 83 & 111 & 69 & 73 & 105 \\
\hline Tłuszcz [g] & 101,1 & 113,4 & 112 & 98,6 & 103,1 & 105 \\
\hline Węglowodany [g] & 346 & 399 & 115 & 267 & 304 & 114 \\
\hline Wapń [mg] & 547 & 636 & 116 & 505 & 523 & 104 \\
\hline Żelazo [mg] & 11,0 & 12,0 & 109 & 10,4 & 10,7 & 104 \\
\hline Witamin A $(\mathrm{mcg})$ & 1099 & 1249 & 114 & 992 & 1029 & 104 \\
\hline Witamin $\mathrm{B}_{1}[\mathrm{mg}]$ & 1,52 & 1,81 & 119 & 1,35 & 1,55 & 115 \\
\hline Witamin $\mathrm{B}_{2}[\mathrm{mg}]$ & 1,55 & 1,81 & 117 & 1,39 & 1,49 & 107 \\
\hline Witamin C [mg] & 96,0 & 94,7 & 99 & 89,7 & 86,2 & 96 \\
\hline Witamin E [mg] & 21,4 & 15,5 & 73 & 22,1 & 18,7 & 84 \\
\hline Potas [mg] & 2954 & 3322 & 112 & 2482 & 2726 & 110 \\
\hline Magnez [mg] & 247 & 277 & 112 & 222 & 232 & 105 \\
\hline
\end{tabular}

*Relacja poziomu spożycia w gospodarstwach rolników $(R)$ do przeciętnego spożycia w gospodarstwach domowych ogółem (O) przyjętego za 100\%.

Źródło danych do obliczeń własnych: GUS, badanie budżetów gospodarstw domowych. GUS nie ponosi odpowiedzialności za dane i wnioski zawarte w publikacji.

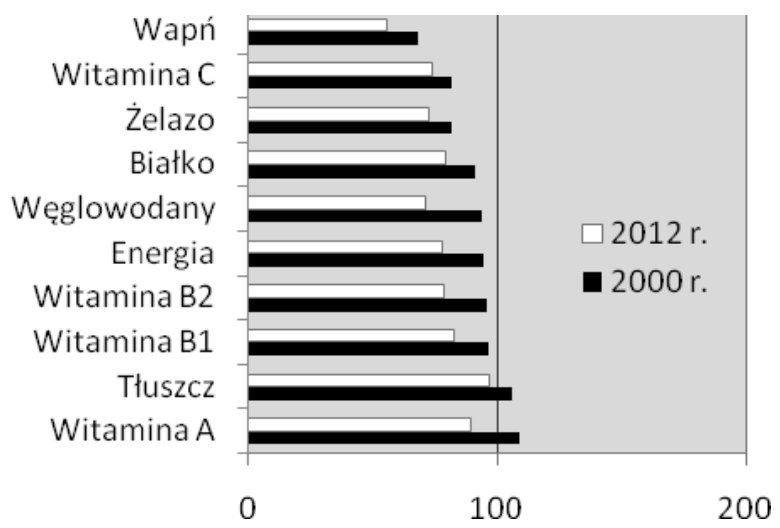

\section{Rysunek 3}

Porównanie [\%] wartości energetycznej i odżywczej przeciętnej racji pokarmowej w gospodarstwach domowych rolników do średnioważonej normy żywienia Źródło: Obliczenia własne. 
Wewnętrzne migracje ludności i będące ich następstwem zmiany w strukturze demograficznej wymagają aby, charakteryzując wiejski wzorzec konsumpcji żywności, nie ograniczać się tylko do rodzin utrzymujących się z rolnictwa, ale uwzględnić wszystkich mieszkańców wsi. Porównanie rocznego spożycia podstawowych grup produktów żywnościowych przez przeciętnego członka gospodarstwa wiejskiego oraz zlokalizowanego na terenie niewielkiego miasta (do 20 tysięcy mieszkańców) wskazuje na wyraźną zmianę wiejskiego wzorca konsumpcji przed akcesją i po niej Polski do UE (tab. 4). W 2000 roku mieszkaniec wsi spożywał o kilkanaście do kilkudziesięciu procent więcej produktów zbożowych, mleka, jaj, tłuszczów zwierzęcych (bez masła), warzyw, roślin strączkowych i cukru niż osoba mieszkająca w małym mieście. Na zbliżonym poziomie konsumowano produkty mięsne, thuszcze roślinne i owoce, natomiast mieszkańcy miast dominowali w konsumpcji ryb i masła. W rok po akcesji do UE zmiana w wiejskim wzorcu konsumpcji polegała na utracie znaczącej przewagi w spożyciu jaj i warzyw (mimo niewielkiego wzrostu konsumpcji) oraz spadku spożycia owoców (średnio o 10\%). W 2012 roku zmiany w sposobie odżywiania się ludności zamieszkałej na wsi były znacznie głębsze, głównie za sprawą obniżenia się, czasem drastycznego (o 20-30\%), konsumpcji produktów roślinnych

\section{Tabela 4}

Poziom spożycia żywności przez przeciętnego członka gospodarstwa domowego na wsi i w małym mieście w latach 2000, 2005 i 2012 (w kg na osobę rocznie)

\begin{tabular}{|l|c|c|c|c|c|c|}
\hline \multirow{2}{*}{ Grupy produktów } & \multicolumn{2}{|c|}{2000} & \multicolumn{2}{c|}{2005} & \multicolumn{2}{c|}{2012} \\
\cline { 2 - 7 } & $\begin{array}{c}\text { Miasto } \\
<20 \text { tys. }\end{array}$ & Wieś & $\begin{array}{c}\text { Miasto } \\
<20 \text { tys. }\end{array}$ & Wieś & $\begin{array}{c}\text { Miasto } \\
<20 \text { tys. }\end{array}$ & Wieś \\
\hline Produkty zbożowe & 111,7 & 128,7 & 108,9 & 120,4 & 84,4 & 94,3 \\
\hline Mięso i przetwory & 67,6 & 71,3 & 73,5 & 72,5 & 73,3 & 72,6 \\
\hline Ryby i przetwory & 5,4 & 4,9 & 5,6 & 4,8 & 5,8 & 4,8 \\
\hline Mleko i przetwory & 86,5 & 102,9 & 82,4 & 89,3 & 73,6 & 75,4 \\
\hline Jaja (w szt.) & 175 & 195 & 197 & 201 & 194 & 204 \\
\hline Masło & 4,0 & 3,5 & 3,9 & 3,4 & 3,4 & 2,7 \\
\hline Tłuszcze roślinne & 13,5 & 13,8 & 14,4 & 14,0 & 13,2 & 13,7 \\
\hline Tłuszcze zwierzęce & 2,3 & 3,9 & 2,6 & 3,4 & 1,7 & 2,1 \\
\hline Owoce i przetwory & 49,6 & 48,2 & 50,2 & 43,6 & 46,6 & 40,9 \\
\hline Warzywa i przetw. & 62,5 & 72,4 & 73,6 & 74,9 & 69,3 & 67,3 \\
\hline Strączkowe suche & 0,9 & 1,3 & 0,8 & 1,0 & 0,6 & 0,7 \\
\hline Ziemniaki & 99,2 & 110,3 & 89,5 & 97,9 & 59,1 & 67,9 \\
\hline Cukier i przetwory & 28,1 & 32,8 & 27,0 & 30,1 & 23,7 & 26,2 \\
\hline
\end{tabular}

Źródło danych do obliczeń własnych: GUS, badanie budżetów gospodarstw domowych. GUS nie ponosi odpowiedzialności za dane i wnioski zawarte w publikacji. 
(ziemniaków, strączkowych, zbożowych, warzyw i owoców), a także mleka i tłuszczów zwierzęcych. Jednak, ponieważ podobne kierunki zmian dotyczyły także spożycia w rodzinach pochodzących z małych miast, wiejski wzorzec konsumpcji zachował w pewnym stopniu swój „tradycyjny” charakter, różniący go od modelu miejskiego.

\section{Podsumowanie}

Makroekonomiczne przemiany związane z włączeniem Polski w struktury Unii Europejskiej nie pozostały bez wpływu na warunki życia ludności, w tym także na sposób odżywiania się. Po objęciu Polski Wspólną Polityką Rolną, zmieniło się funkcjonowanie gospodarstw rolnych, do czego przyczynił się m.in. dostęp do jednolitego rynku europejskiego i możliwości korzystania ze wsparcia $\mathrm{z}$ funduszy unijnych. Dzięki temu poprawiła się kondycja części gospodarstw (o większej powierzchni), ale jednocześnie miało miejsce zmniejszenie się ich ogólnej liczby (te o najmniejszej powierzchni stały się nieopłacalne), co z kolei spowodowało spadek zatrudnienia w rolnictwie, konieczność szukania pracy w innych sektorach gospodarki, ukryte bezrobocie na wsi. Dochody rodzin utrzymujących się z rolnictwa pozostały niższe od dochodów rodzin miejskich. Wskutek dodatniego salda migracji wewnętrznych zmieniła się struktura mieszkańców wsi.

W efekcie powyższych zmian rok po akcesji do UE (2005) zaobserwowano korzystne zmiany wzorca konsumpcji realizowanego w gospodarstwach rolników w stosunku do przeciętnego polskiego gospodarstwa domowego - dominowały one w spożyciu zdecydowanej większości grup produktów żywnościowych, tylko owoce spożywano na tym samym poziomie.

W 2012 roku rolniczy wzorzec konsumpcji stał się znów bardziej ,tradycyjny”, czyli bazujący na artykułach pochodzących z samozaopatrzenia, zwłaszcza w odniesieniu do jaj, tłuszczów zwierzęcych i ziemniaków oraz charakteryzujący się niższym niż w przeciętnym gospodarstwie spożyciem owoców, ryb i masła. Jednocześnie, w stosunku do 2000 roku, znacząco obniżyła się jego wartość energetyczna i odżywcza. Stwierdzono istnienie potencjalnych niedoborów większości witamin i składników mineralnych w gospodarstwach rolników, dotyczących zwłaszcza wapnia, żelaza i witaminy C.

Porównanie konsumpcji żywności przez przeciętnego mieszkańca wsi ze spożyciem żywności przez osobę mieszkającą w małym mieście wykazało, że największy stopień zbliżenia obu wzorców miał miejsce w 2012 roku, choć nadal różniło je spożycie produktów pochodzących z samozaopatrzenia (większe na wsi) oraz owoców i ryb (wyraźnie mniejsze na wsi). Zdecydowały o tym istniejące różnice w zamożności ludności miast i wsi na niekorzyść tych ostatnich. 


\section{Literatura}

JAROSZ M. (red. nauk.), 2012: Normy żywienia dla populacji polskiej - nowelizacja, red. naukowy, IŻŻ, 2012, www.izz.waw.pl

KAMIŃSKI W., 1980: Polityka i organizacja żywienia ludności, PWE, Warszawa.

KOWRYGO B., 2000: Studium wplywu gospodarki rynkowej na sferę żywności i żywienia $w$ Polsce. Wyd. SGGW, Warszawa, s. 187.

KUNACHOWICZ H., PRZYGODA B., NADOLNA I., IWANOW K., 2005: Tabele Składu i Wartości Odżywczej Żywności, Wyd. Lekarskie PZWL, Warszawa.

LASKOWSKI W., ŚWISTAK E. 2014: Zmiany we wzorcach spożycia żywności w Polsce. Wyd. Laskowski, Warszawa, s. 7.

POCZTA W., 2008: Wplyw integracji Polski z Uniq Europejska na sytuacje ekonomiczna sektora rolnego w latach 2004-2006. Wieś i Rolnictwo 1 (138), s. 19-33.

Rocznik Statystyczny Rolnictwa 2007, Zakład Wyd. Statystycznych, Warszawa.

Rocznik Statystyczny Rolnictwa 2014, Zakład Wyd. Statystycznych, Warszawa.

Rocznik Statystyczny Rzeczypospolitej Polskiej 2014, Zakład Wyd. Statystycznych, Warszawa.

Wieś polska - rdzenni i nowi mieszkańcy. Komunikat z badań CBOS, BS/120/2013, Warszawa, sierpień 2013. www.cbos.pl

WISZNIEWSKI E., Ekonomika konsumpcji, PWN, Warszawa 1983.

ZEGAR J.S., 2015: Polskie rolnictwo w okresie dwóch przełomów - transformacji ustrojowej i integracji europejskiej. Nierówności Społeczne a Wzrost Gospodarczy nr 41. www.ur.edu.pl/file/85907/9\%20Zegar\%20J.S..pdf

\section{Abstrakt}

Zachodzące w ostatnich latach w Polsce zmiany w strukturze zatrudnienia, będące m.in. następstwem dynamicznego rozwoju sektora usług, przy malejącej roli takich działów gospodarki jak przemysł czy rolnictwo, wywołały migracje ludności, w efekcie których zmieniła się struktura mieszkańców wsi. Zmiany te, jak również dochodowe i demograficzne, nie pozostały bez wpływu na sposób odżywiania się ludności, wskutek czego wiejski wzorzec konsumpcji żywności utracił częściowo swoje tradycyjne cechy. Jednak, w przeciwieństwie do modelu miejskiego, w dalszym ciągu charakteryzuje go wyższy udział produktów pochodzących z samozaopatrzenia i niskie spożycie ryb i owoców.

Słowa kluczowe: wzorzec konsumpcji żywności, wiejskie gospodarstwa domowe, uwarunkowania ekonomiczne i demograficzne, migracje ludności 


\title{
Food consumption changes in rural areas and their determinants
}

\begin{abstract}
Recent changes in the structure of employment in Poland, resulting from dynamic development of the services sector as well as diminishing roles of industry and agriculture, led to migrations and in consequence to the change of rural habitants structure. These changes, as well as economic and demographic ones, caused changes in the food consumption pattern; among others, rural food consumption pattern has lost some of its traditional features. However, unlike in urban model, it is still characterized by a higher proportion of products derived from the selfsupply as well as low consumption of fruit and fish.
\end{abstract}

Key words: food consumption pattern, rural households, economic and demographic conditions, migrations 